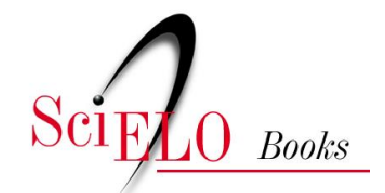

\title{
Declaração sobre a política do partido comunista brasileiro
}

\author{
Raimundo Santos
}

SANTOS, R. Agraristas políticos brasileiros [online]. Rio de Janeiro: Centro Edelstein de Pesquisas Sociais, 2008. pp. 129-153. Declaração sobre a política do partido comunista brasileiro. ISBN: 978-

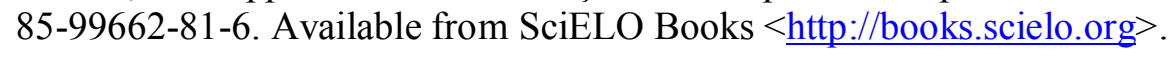

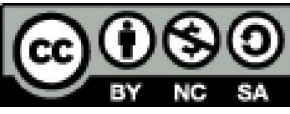

All the contents of this chapter, except where otherwise noted, is licensed under a Creative Commons Attribution-Non Commercial-ShareAlike 3.0 Unported.

Todo o conteúdo deste capítulo, exceto quando houver ressalva, é publicado sob a licença Creative Commons Atribuição Uso Não Comercial - Partilha nos Mesmos Termos 3.0 Não adaptada.

Todo el contenido de este capítulo, excepto donde se indique lo contrario, está bajo licencia de la licencia Creative Commons Reconocimento-NoComercial-CompartirIgual 3.0 Unported. 


\section{III - PARTE APÊNDICE}

\section{DeClaração Sobre a Política do Partido Comunista Brasileiro ${ }^{1}$}

Os documentos do XX Congresso do PCUS motivaram nas fileiras do nosso Partido intensa discussão, no curso da qual foram submetidos à crítica os graves erros de caráter dogmático e sectário da orientação política do Partido.

O exame destes erros e a necessidade de superá-los levaram o Comitê Central do PCB a traçar uma nova orientação política, que é exposta na presente declaração. Ao fazê-lo, o Comitê Central considerou a experiência passada do Partido e as modificações essenciais ocorridas na situação do Brasil e do mundo.

O Comitê Central espera que, no processo de sua aplicação prática, a política aqui traçada seja submetida à comprovação e enriquecida pela experiência do Partido e do povo brasileiro.

\section{I - O processo de desenvolvimento econômico do Brasil}

Modificações importantes têm ocorrido, durante as últimas décadas, na estrutura econômica que o Brasil herdou do passado, definido pelas seguintes características: agricultura baseada no latifúndio e nas relações pré-capitalistas de trabalho, predomínio maciço da produção agropecuária no conjunto da produção, exportação de produtos agrícolas como eixo de toda a vida econômica, dependência da economia nacional em relação ao estrangeiro, através do comércio exterior e da penetração do capital monopolista nos postos-chave da produção e da circulação.

${ }^{1}$ Esta resolução do Comitê Central do PCB foi publicada no jornal Voz Operária, 22 de março de 1958 .
Nos quadros dessa estrutura atrasada, foi-se processando um desenvolvimento capitalista nacional, que constitui o elemento progressista por excelência da economia brasileira. Este desenvolvimento inelutável do capitalismo consiste no incremento das forças produtivas e na expansão, na base material da sociedade, de novas relações de produção, mais avançadas.

Por sua própria natureza e ainda por se chocar com a resistência de elementos econômicos atrasados e sofrer a pressão do imperialismo, o desenvolvimento capitalista nacional vem-se realizando num ritmo bastante desigual, se bem que tenha se acelerado nos últimos vinte anos.

O desenvolvimento capitalista nacional já trouxe resultados que modificaram sensivelmente a vida econômica e social do país. Assim é que foi construído no Brasil um parque industrial, que abastece o mercado interno da quase totalidade de artigos de consumo comum. A indústria de meios de produção elevou a sua participação de 20 a $33 \%$ no conjunto da produção industrial, entre os anos de 1939 a 1956. Num prazo relativamente breve, de 1944 a 1956, o volume físico da produção industrial total foi duplicado. Surgiu e se fortaleceu no setor da indústria pesada um capitalismo de Estado de caráter nacional e progressista, que abrange empresas poderosas como a Petrobrás e a Companhia Siderúrgica Nacional Embora mais lentamente, também na agricultura vem-se desenvolvendo o capitalismo, que se traduz no crescimento do número de assalariados e semiassalariados, bem como na multiplicação da quantidade de máquinas e instrumentos agrários. Ampliou-se de modo acentuado o mercado interno, sendo que o volume do comércio de cabotagem entre 1921 e 1955 aumentou de cinco vezes.

Em consequência do desenvolvimento capitalista, cresceram os efetivos do proletariado industrial e aumentou o seu peso específico no conjunto da população. Enquanto esta duplicou de 1920 até hoje, o número de operários industriais aumentou de sete vezes no mesmo período, passando de 275.000 a cerca de 2 milhões. Simultaneamente, surgiu e se fortaleceu cada vez mais uma burguesia interessada no desenvolvimento independente e progressista da economia do país.

O desenvolvimento capitalista, entretanto, não conseguiu eliminar os fatores negativos, que determinam as características do Brasil como país subdesenvolvido. Ao tempo em que se incrementam as forças produtivas e progridem, as novas relações de produção capitalistas, conservam-se em 
vastas áreas as relações atrasadas e permanece a dependência diante do imperialismo particularmente o norte-americano.

Com a penetração do capitalismo na agricultura, combinam-se, em proporção variável, os métodos capitalistas à conservação do monopólio da terra e das velhas relações semifeudais, o que permite um grau mais elevado de exploração dos trabalhadores do campo. O Brasil continua a ser um país de grande concentração latifundiária: em 1950, os estabelecimentos agrícolas com 500 hectares e mais constituíam 3,4\% do número total de estabelecimento e abrangiam $62,3 \%$ de toda a área ocupada. As sobrevivências feudais obstaculizam o progresso da agricultura, que se realiza, em geral, lentamente, mantém o baixíssimo nível de vida das massas camponesas e restringem de modo considerável as possibilidades de expansão do mercado interno. As sobrevivências feudais são um dos fatores que acentuam a extrema desigualdade de desenvolvimento das diferentes regiões do país, especialmente entre o sul e parte do leste, que se industrializam, e o resto do país, quase inteiramente agrário.

Apesar de detida sua penetração em algumas importantes esferas da economia brasileira, o imperialismo continua a dominar posições-chave em ramos fundamentais. Esta penetração é realizada em elevado grau sobretudo pelos monopólios norte-americanos que, a partir da segunda guerra mundial, alcançaram o predomínio absoluto sobre os seus competidores. Os investimentos diretos norte-americanos aumentaram de 193,6 milhões de dólares, em 1929, para 1.107 milhões de dólares em 1955. Cerca de 60\% dos financiamentos estrangeiros procedem dos Estados Unidos. Mais de um terço do comércio exterior brasileiro é realizado com os Estados Unidos, que, além disso, dominam o mercado internacional de nossos principais produtos de exportação e podem, assim, fazer do comércio exterior um instrumento de controle da vida econômica e política do país.

Mantendo embora o seu predomínio, o imperialismo norte americano enfrenta no Brasil a crescente concorrência de outras potências imperialistas, principalmente da Alemanha Ocidental e da Inglaterra.

A exploração imperialista impõe pesado tributo à nação, transferindo para o exterior considerável parte do valor criado pelos trabalhadores brasileiros, o que reduz, em consequência, a taxa de acumulação capitalista no país, diminui o ritmo do seu progresso e influi no baixo nível de vida da sua população.
A independência política do Brasil sofre sérias restrições em virtude da situação de dependência econômica. À medida que a nação se desenvolve, aguça-se o seu antagonismo com o imperialismo norte americano. O desenvolvimento capitalista nacional exige cada vez mais, como seu instrumento, uma independência política completa, que se traduza numa política exterior independente e na proteção consequente do capital nacional contra o capital monopolista estrangeiro.

O processo de democratização se reflete no Parlamento. É verdade que os setores reacionários e entreguistas ainda possuem poderosas posições naquela instituição e conseguem impor decisões opostas aos interesses nacionais, a exemplo da aprovação do Acordo Militar Brasil Estados Unidos, da rejeição de uma legislação social para os trabalhadores do campo e da cassação do direito de representação parlamentar para o Partido Comunista. É igualmente inegável, porém, que vem aumentando nas sucessivas legislaturas o número de parlamentares nacionalistas e democráticos integrantes dos mais variados partidos. Isto indica o aumento da influência da burguesia nesses partidos e a utilização do voto por grandes setores das massas, particularmente do proletariado, para apoiar uma política nacionalista e democrática. Se bem que o processo eleitoral ainda esteja submetido a restrições antidemocráticas, as massas têm conseguido influir na composição do parlamento e pressionando sobre ele com a ação extraparlamentar, já o levaram a adotar decisões positivas para a emancipação nacional, a exemplo do monopólio estatal do petróleo e da política nacionalista dos minerais atômicos.

O processo de desenvolvimento capitalista e a participação da burguesia no poder do Estado se refletem também na composição do atual governo. Em decorrência da coligação de que surgiu, o governo do Sr. Juscelino Kubitschek tomou um caráter heterogêneo, com um setor entreguista ao lado de um setor nacionalista burguês.

A composição do governo do Sr. Juscelino Kubitschek é, em virtude disso, o resultado de um compromisso entre as duas alas que o integram. Este compromisso é frágil, não anula as contradições internas do governo e não impede a luta que lavra no seu seio. Apoiado nas massas, na Frente Parlamentar Nacionalista e no setor nacionalista das Forças Armadas, o setor nacionalista do governo tem influído para importantes decisões positivas. Disto são exemplos expressivos a defesa do monopólio estatal do petróleo e a 
manutenção de um clima de legalidade constitucional na vida política. Por outro lado, sob a pressão do setor entreguista e do imperialismo norteamericano, os elementos nacionalistas do governo têm sido levados a vacilações, derrotas e mesmo a graves capitulações, como foi o caso da cessão do arquipélago de Fernando de Noronha aos Estados Unidos.

As contradições existentes no seio do governo se manifestam em todas as esferas de sua atividade.

A política exterior permanece em geral caudatária do Departamento de Estado norte-americano, mas se fortalece a pressão do setor nacionalista por importantes modificações, como a exigência do estabelecimento de relações com a União Soviética e demais países socialistas.

O governo tem desenvolvido, apoiado no povo, formas nacionais e progressistas de capitalismo de Estado, a exemplo da Petrobrás e de Volta Redonda. O capitalismo de Estado vem sendo um elemento progressista e anti-imperialista da política econômica do governo, mas este ainda permite que empresas de capitalismo de Estado realizem uma política favorável ao imperialismo, como no caso dos financiamentos do BNDE ou da distribuição, pelos trustes, da energia produzida nas centrais elétricas estatais.

Enquanto toma medidas de interesse nacional, ao defender o café contra a especulação das firmas norte-americanas no mercado interno e mundial, o governo continua a propiciar inversões imperialistas à base de excepcionais privilégios, que suscitam protestos dos círculos mais representativos da burguesia. As medidas de reforma agrária não figuram sequer nos planos governamentais. A inflação e a carestia de vida continuam sendo fatores de instabilidade da economia nacional e de crescentes dificuldades para as massas.

Enquanto altera a velha estrutura econômica e cria uma nova e mais avançada, o desenvolvimento capitalista nacional entra em conflito com a exploração imperialista e a estrutura tradicional arcaica e em decomposição. Este desenvolvimento se processa através de contradições, de avanços e recuos, mas é a tendência que abre caminho e se fortalece.

\section{II - A democratização da vida política nacional}

O desenvolvimento capitalista do país não podia deixar de refletir-se no caráter do Estado brasileiro, em seu regime político e na composição do governo.

O Estado brasileiro atualmente representa os interesses dos latifundiários, dos setores de capitalistas ligados ao imperialismo, particularmente ao norte-americano, e também da burguesia interessada no desenvolvimento independente da economia nacional. Daí surgem contradições e tipos diversos de compromisso de classe no seio do próprio Estado. Os diferentes interesses de classe representados nos órgãos do Estado encontram pontos de contato e de acordo mas, ao mesmo tempo, lutam entre si para impor determinados rumos à política estatal, chegando por vezes a conflito aberto, como em agosto de 1954 e em novembro de 1955.

As forças novas que crescem no seio da sociedade brasileira, principalmente o proletariado e a burguesia, vêm impondo um novo curso ao desenvolvimento político do país, com o declínio da tradicional influência conservadora dos latifundiários. Este novo curso se realiza no sentido da democratização, da extensão dos direitos políticos a camadas cada vez mais amplas.

A democratização do regime político do país, que tomou impulso com os acontecimentos de 1930, não segue o seu curso em linha reta, mas, enfrentando a oposição das forças reacionárias e pró-imperialistas, sofre, em certos momentos, retrocessos ou brutais interrupções, como sucedeu com o Estado Novo, com a ofensiva reacionária de 1947 ou por ocasião do golpe de 1954. Mas o processo de democratização é uma tendência permanente. Por isto, pode superar quaisquer retrocessos e seguir incoercivelmente para diante. Vem-se firmando, assim, em nosso país, a legalidade democrática, que é defendida por amplas e poderosas forças sociais.

A Constituição promulgada em 1946 encerra traços reacionários que resultaram da correlação de forças existente na época de sua elaboração e expressam aspectos retrógrados da estrutura econômico-social brasileira. Ao mesmo tempo, a Constituição consagra as liberdades democráticas e os direitos sociais das massas alcançados após a derrota mundial no nazifascismo e do Estado Novo em nosso país: as liberdades de expressão, inclusive de imprensa, de reunião e de organização, o direito de greve, etc. 
As massas trabalhadoras das cidades têm obtido vitórias na justa luta pela concretização de seus direitos já consolidados em lei, como a liberdade sindical, a previdência social e outros. A democratização do país também influi, menos acentuadamente, nas zonas rurais, onde o tradicional despotismo dos grandes senhores de terra é obrigado a ceder terreno, conquanto ainda perdure. Os atentados cometidos pelos elementos reacionários do aparelho do Estado encontram a resistência cada vez mais eficiente das massas na defesa das liberdades e dos direitos constitucionais. Tudo isso explica por que, no curso da vida política recente do país, as forças nacionalistas e democráticas se colocaram ao lado da Constituição, como sucedeu a 24 de agosto de 1954 e a 11 de novembro de 1955, ao passo que as forças golpistas pró-imperialistas atentaram contra ela.

A política do governo do Sr. Juscelino Kubitschek não atende, assim, aos interesses nacionais e às aspirações das massas populares em questões essenciais, contendo, entretanto, aspectos positivos de caráter nacionalista e democrático. À medida que os aspectos negativos da atuação do governo se tornam mais evidentes, acentua-se a luta por modificações na sua composição e na sua política num sentido favorável aos interesses nacionais e populares. Esta luta é apoiada pelo setor nacionalista do próprio governo e aprofunda as suas contradições com o setor entreguista.

É na luta contra o imperialismo norte-americano e os seus agentes internos que as forças progressistas da sociedade brasileira podem acelerar o desenvolvimento econômico independente e o processo de democratização da vida política do país. Para atingir este objetivo, as forças progressistas têm interesse em defender, estender e consolidar o regime de legalidade constitucional e democrático.

\section{III - Crescem no mundo inteiro as forças da paz, da democracia e do socialismo}

$\mathrm{Na}$ situação do Brasil, no desenvolvimento de suas forças antiimperialistas e democráticas, influem poderosamente as modificações essenciais verificadas na situação internacional, sobretudo após a segunda guerra mundial.

A característica nova e principal de nossa época, o seu conteúdo fundamental, é a transição do capitalismo ao socialismo, iniciada pela
Grande Revolução Socialista de Outubro na Rússia. O socialismo ultrapassou os marcos de um só país e se transformou num sistema mundial vigoroso e florescente, que exerce influência positiva na evolução política e social de todos os povos. São enormes os êxitos econômicos e culturais dos países socialistas, e em primeiro lugar da União Soviética, que já assumiu a vanguarda em importantes ramos da ciência e da tecnologia, marchando para superar, em breve prazo histórico, o país capitalista mais adiantado, os Estados Unidos, quanto aos índices fundamentais da produção por habitante. Estes êxitos crescentes atraem para a ideia do socialismo a consciência das grandes massas de todos os continentes. Aplicando com justeza os princípios do marxismo-leninismo às condições nacionais específicas, fortalecem-se os partidos comunistas e operários de numerosos países do mundo capitalista.

O movimento comunista mundial elevou a novo nível a sua unidade. A luta da classe operária obtém grandiosas vitórias e constitui uma força decisiva na situação internacional.

Fato novo de imensa significação é o adiantado processo de desagregação do sistema colonial do imperialismo. Populações de mais de um bilhão de pessoas se libertaram do jugo colonial e alcançaram a independência política, enquanto os povos ainda submetidos aquele jugo intensificam a sua luta de libertação, colocando em situação cada vez mais difícil as potências imperialistas. Surgiu no mundo uma vasta zona de paz, que abrange os países socialistas e os países da Ásia e da África amantes da paz e promotores de uma política de defesa da sua soberania e de emancipação econômica.

A luta contra o imperialismo norte-americano, pela democracia e pela paz eleva o seu nível na América Latina. As ditaduras terroristas a serviço dos monopólios dos Estados Unidos estão sendo derrubadas, o que abre caminho para o avanço do processo democrático e emancipador. A política de chantagem guerreira praticada pelos círculos de Washington vem fracassando na América Latina, à medida que se acentua o alívio da tensão internacional.

Em consequência do impetuoso ascenso do socialismo e das vitórias do movimento de libertação nacional, acelerou-se o processo de debilitamento e decomposição do imperialismo. Não só se reduziu drasticamente a área do seu domínio, como se agravaram as contradições 
entre os países imperialistas e dentro de cada um deles. Aumentam as dificuldades econômicas nos Estados Unidos, onde a produção vem caindo, enquanto cresce o número de desempregados, o que delineia uma perspectiva de crise econômica.

O imperialismo norte-americano é o centro da reação mundial. Segue uma política de atentados contra a soberania nacional de todos os povos, de corrida armamentista e preparativos de uma terceira guerra mundial, que seria a mais terrível catástrofe para a humanidade.

As guerras de agressão continuam a encontrar terreno na existência do imperialismo e este ainda tem desencadeado bárbaros atentados contra numerosos povos. Em virtude, porém, da correlação de forças favorável ao socialismo e às forças amantes da paz, surgiu em nossa época a possibilidade real de impedir as guerras. A luta pela paz - tarefa primordial de todos os povos - tem condições para ser plenamente vitoriosa. A política consequente de coexistência pacífica praticada pela União Soviética e pelos demais países socialistas ganha a simpatia dos povos, desfaz as manobras da "guerra fria" e consegue resultados concretos no sentido do alívio da tensão internacional. A rápida cessação da agressão imperialista ao Egito mostrou mais uma vez que a causa da paz e da libertação nacional tem a seu favor forças mais poderosas do que os agentes da guerra.

As modificações na arena internacional criam condições mais favoráveis para a luta pelo socialismo, tornam mais variados os caminhos da conquista do poder pela classe operária e as formas de construção da nova sociedade. A possibilidade de uma transição pacífica ao socialismo se tornou real numa série de países.

O ascenso do socialismo, da causa da paz e do movimento de libertação nacional no mundo inteiro influi de modo positivo no crescimento das forças políticas anti-imperialistas e democráticas no Brasil.

A nova situação internacional cria condições favoráveis ao desenvolvimento econômico de nosso país, à libertação da dependência em relação ao imperialismo, à democratização da vida política nacional. Estas condições são especialmente favoráveis à aplicação de uma política externa independente e de paz, em benefício da emancipação econômica da nação. Uma política desta ordem, que muitos países do mundo capitalista já praticam, encontra o apoio de poderosas forças que atuam no cenário mundial.
Conquanto se beneficie da influência dos fatores positivos da situação internacional, o povo brasileiro é obrigado a enfrentar a pressão e os atentados do imperialismo norte-americano, que ocupa posições-chave na economia de nosso país e interfere nas questões de sua política interna e externa. Não obstante as derrotas que tem sofrido, não cessa a penetração econômica dos monopólios norte-americanos. Os círculos dirigentes dos Estados Unidos, com o apoio dos setores entreguistas, tomam medidas para vincular o Brasil aos preparativos bélicos e aos planos de uma terceira guerra mundial. Esta é a mais grave ameaça que pesa sobre a nossa pátria e contra esta ameaça tendem a unir-se todos os brasileiros favoráveis à manutenção da paz.

A luta contra o imperialismo norte-americano, pela independência nacional do Brasil, é parte integrante da luta pela paz mundial. As vitórias da causa da paz no mundo inteiro contribuem para os êxitos da luta emancipadora de nosso povo. Existem condições para derrotar a política de dependência ao imperialismo norte-americano e anular suas ameaças. A situação internacional é favorável às forças que lutam pela paz, pela emancipação nacional e pela democracia no Brasil.

\section{IV - Aprofunda-se a contradição entre a nação brasileira e o imperialismo norte-americano}

As modificações na situação econômica e política do país, bem como na situação internacional, determinam importantes alterações na disposição das forças sociais e definem o caminho para a solução dos problemas da revolução brasileira.

Como decorrência da exploração imperialista norte-americana e da permanência do monopólio da terra, a sociedade brasileira está submetida, na etapa atual de sua história, a duas contradições fundamentais.

A primeira é a contradição entre a nação e o imperialismo norteamericano e seus agentes internos. A segunda e a contradição entre as forças produtivas em desenvolvimento e as relações de produção semifeudais na agricultura. O desenvolvimento econômico e social do Brasil toma necessária a solução dessas duas contradições fundamentais.

A sociedade brasileira encerra também a contradição entre o proletariado e a burguesia, que se expressa nas várias formas da luta de 
classes entre operários e capitalistas. Mas esta contradição não exige uma solução radical na etapa atual. Nas condições presentes de nosso país, o desenvolvimento capitalista corresponde aos interesses do proletariado e de todo o povo.

A revolução no Brasil, por conseguinte, não é ainda socialista, mas anti-imperialista e antifeudal, nacional e democrática. A solução completa dos problemas que ela apresenta deve levar à inteira libertação econômica e política da dependência para com o imperialismo norte-americano; à transformação radical da estrutura agrária, com a liquidação do monopólio da terra e das relações pré-capitalistas de trabalho; ao desenvolvimento independente e progressista da economia nacional e à democratização radical da vida política. Estas transformações removerão as causas profundas do atraso de nosso povo e criarão, com um poder das forças antiimperialistas e antifeudais sob a direção do proletariado, as condições para a transição ao socialismo, objetivo não imediato, mas final, da classe operária brasileira.

Na situação atual do Brasil, o desenvolvimento econômico capitalista entra em choque com a exploração imperialista norte-americana, aprofundando-se a contradição entre as forças nacionais e progressistas em crescimento e o imperialismo norte-americano, que obstaculiza a sua expansão. Nestas condições, a contradição entre a nação em desenvolvimento e o imperialismo norte-americano e os seus agentes internos tornou-se a contradição principal na sociedade brasileira.

O golpe principal das forças nacionais, progressistas e democráticas se dirige, por isto, atualmente, contra o imperialismo norte-americano e os entreguistas que o apoiam. A derrota da política do imperialismo norteamericano e de seus agentes internos abrirá caminho para a solução de todos os demais problemas da revolução nacional e democrática no Brasil.

Para realizar a sua política de exploração e de vinculação de nosso país aos seus planos guerreiros, o imperialismo norte-americano conta com o apoio de setores de latifundiários e de setores da burguesia. Servem ao imperialismo norte-americano os latifundiários que estão ligados, por seus interesses, à exploração imperialista, numerosos intermediários do comércio exterior, os sócios de empresas controladas pelo capital monopolista norteamericano e determinados agentes de negócios bancários e comerciais.
Estes setores - minoria verdadeiramente ínfima - constituem as forças entreguistas que, dentro e fora dos órgãos de Estado, sustentam a política de dependência ao imperialismo norte-americano.

Ao inimigo principal da nação brasileira se opõem, porém, forças muito amplas. Estas forças incluem o proletariado, lutador mais consequente pelos interesses gerais da nação; os camponeses, interessados em liquidar uma estrutura retrógrada que se apoia na exploração imperialista; a pequena burguesia urbana, que não pode expandir as suas atividades em virtude dos fatores de atraso do país; a burguesia, interessada no desenvolvimento independente e progressista da economia nacional; os setores de latifundiários que possuem contradições com o imperialismo norte-americano, derivadas da disputa em torno dos preços dos produtos de exportação, da concorrência no mercado internacional ou da ação extorsiva de firmas norte-americanas e de seus agentes no mercado interno; os grupos da burguesia ligados a monopólios imperialistas rivais dos monopólios dos Estados Unidos e que são prejudicados por estes.

São forças, portanto, extremamente heterogêneas pelo seu caráter de classe. Incluem desde o proletariado, que tem interesse nas mais profundas transformações revolucionárias, até parcelas das forças mais conservadoras da sociedade brasileira. A sua consequência na luta contra o imperialismo norte-americano não pode ser evidentemente a mesma, porém todas essas forças possuem motivos para se unirem contra a política de submissão ao imperialismo norte-americano. Quanto mais ampla for esta unidade, maiores serão as possibilidades de infligir uma derrota completa àquela política e garantir um curso independente, progressista e democrático ao desenvolvimento da nação brasileira.

\section{V - A frente única e a luta por um governo nacionalista e democrático}

As tarefas impostas pela necessidade do desenvolvimento independente e progressista do país não podem ser resolvidas por nenhuma força social isoladamente. Disto decorre a exigência objetiva aliança entre todas as forças interessadas na luta contra a política de submissão ao imperialismo norte-americano. A experiência da vida política brasileira tem demonstrado que as vitórias anti-imperialistas e democráticas só puderam ser obtidas pela atuação em frente única daquelas forças. 
A frente única se manifesta nas múltiplas formas concretas de atuação ou de organização em comum, que surgem no país, por iniciativas de diferentes origens e de acordo com as exigências da situação. Entre estas formas, a mais importante atualmente é o movimento nacionalista. O seu desenvolvimento expressa um grau mais elevado de unidade e concentração das forças anti-imperialistas. Constituiu um fato novo, resultante não só de fatores objetivos, entre os quais o desenvolvimento do capitalismo, que fortaleceu as posições da burguesia, como também das lutas patrióticas de massas, que se travaram durante muitos anos com a participação combativa do proletariado e de sua vanguarda comunista. Tendem a unir-se e podem efetivamente unir-se no movimento nacionalista a classe operária, os camponeses, a pequena burguesia urbana, a burguesia e os setores de latifundiários que possuem contradições com o imperialismo norte-americano.

O movimento nacionalista vem exercendo influência para elevar a consciência anti-imperialista das massas e para agrupar os setores nacionalistas dos partidos políticos, do parlamento, das Forças Armadas e do próprio governo. Superando as divergências que existem entre os seus participantes, o movimento nacionalista atrai para a sua frente de luta entidades, partidos, correntes e personalidades do mais variado caráter social e orientação política. Assim é que a Frente Parlamentar Nacionalista, cujo aparecimento tem notável significação em nossa vida política, unificou a ação de grande número de parlamentares pertencentes aos mais diversos partidos com representação no Congresso, quer sejam governistas ou oposicionistas.

O movimento nacionalista vem surgindo nas diferentes regiões com plataformas que, ao lado de pontos comuns, apresentam questões variadas, de acordo com a influência de determinadas forças políticas e da maior sensibilidade, por motivos locais, a esta ou aquela reivindicação antiimperialista. Os comunistas consideram que é necessário tudo fazer, dentro do mais alto espírito de unidade, para impulsionar o movimento nacionalista, ampliar seu caráter de massas e ajudar sua coordenação em escala nacional. Isto contribuirá para acelerar a polarização em processo entre às forças anti-imperialistas e democráticas de um lado, e as forças entreguistas do outro lado.

Os comunistas devem ser um fator por excelência unitário dentro da frente única nacionalista e democrática. Por isto, não condicionam a sua permanência na frente única à total aceitação de suas opiniões. Os participantes da frente única poderão aceitar essas opiniões somente como resultado de sua justeza, de sua força persuasiva e, acima de tudo, da sua comprovação pela experiência política concreta. Defendendo firmemente suas opiniões, os comunistas consideram que, se forem justas, tais opiniões acabarão sendo aceitas pelas massas e pelos aliados, vindo a prevalecer através de processos democráticos, dentro da frente única. Os comunistas não são exclusivistas e, ao mesmo tempo que encaram com espírito autocrítico a sua própria atividade, aceitam e valorizam as opiniões corretas procedentes das outras forças da frente única.

Sendo inevitavelmente heterogênea, a frente única nacionalista e democrática encerra contradições. Por um lado, há interesses comuns e, portanto, há unidade. Este é um aspecto fundamental e explica a necessidade da existência da frente única, a sua capacidade de superar as contradições internas entre os seus componentes. Por outro lado, há interesses contraditórios e, portanto, as forças sociais integrantes da frente única se opõem no terreno de certas questões, esforçando-se para fazer prevalecer seus interesses e pontos de vista.

O proletariado e a burguesia se aliam em torno do objetivo comum de lutar por um desenvolvimento independente e progressista contra o imperialismo norte-americano. Embora explorado pela burguesia, é do interesse do proletariado aliar-se a ela, uma vez que sofre mais do atraso do país e da exploração imperialista do que do desenvolvimento capitalista. Entretanto, marchando unidos para atingir um objetivo comum, a burguesia e o proletariado possuem também interesses contraditórios.

A burguesia se empenha em recolher para si todos os frutos do desenvolvimento econômico do país, intensificando a exploração das massas trabalhadoras e lançando sobre elas o peso das dificuldades. Por isto, a burguesia é uma força revolucionária inconsequente, que vacila em certos momentos, tende aos compromissos com os setores entreguistas e teme a ação independente das massas.

$\mathrm{O}$ proletariado tem interesse no desenvolvimento anti-imperialista e democrático consequente. A fim de assegurá-lo, ao mesmo tempo que luta pela causa comum de todas as classes e camadas que se opõem à exploração imperialista norte-americana, o proletariado defende os seus interesses específicos e os das vastas massas trabalhadoras e bate-se por amplas liberdades democráticas, que facilitem a ação independente das massas. $\mathrm{O}$ 
proletariado deve salvaguardar, por isto, a sua independência ideológica, política e organizativa dentro da frente única.

É indispensável; entretanto, jamais perder de vista que a luta dentro da frente única é diferente, em princípio, da luta que a frente única trava contra o imperialismo norte-americano e as forças entreguistas. Neste último caso, o objetivo consiste em isolar o inimigo principal da nação brasileira e derrotar a sua política. Já a luta do proletariado dentro da frente única não tem por fïm isolar a burguesia nem romper a aliança com ela, mas visa a defender os interesses específicos do proletariado e das vastas massas, simultaneamente ganhando a própria burguesia e as demais forças para aumentar a coesão da frente única. Por se travar dentro da frente única, esta luta deve ser conduzida de modo adequado, através da crítica ou de outras formas, evitando elevar as contradições internas da frente única ao mesmo nível da contradição principal, que opõe a nação ao imperialismo norte-americano e seus agentes. Assim, é preciso ter sempre em vista que as contradições de interesses e divergências de opinião dentro da frente única, embora não devam ser ocultadas e venham a causar dificuldades, podem ser abordadas e superadas sem romper a unidade.

Os comunistas de modo algum condicionam a sua participação na frente única a uma prévia direção do movimento. Tendo por objetivo a ampliação e a coesão da frente única, os comunistas trabalham para que as forças anti-imperialistas e democráticas, principalmente as grandes massas da cidade e do campo, aceitem a direção do proletariado, uma vez que esta direção é, do ponto de vista histórico, a única capaz de dar à frente única firmeza e consequência política. A conquista da hegemonia do proletariado é, porém, um processo de luta árduo e paulatino, que avançará à medida em que a classe operária forjar a sua unidade, estabelecer laços de aliança com os camponeses e defender de modo acertado os interesses comuns de todas as forças que participam da frente única.

Para a unidade da classe operária, tem grande importância o fortalecimento do movimento sindical. Este alcançou numerosas vitórias nos últimos tempos, possibilitando aos trabalhadores defender o seu nível de vida, restabelecer a liberdade sindical e elevar o seu grau de unidade e organização. As organizações intersindicais têm contribuído para a unidade da classe operária, mas a experiência vem demonstrando que o movimento sindical tem avançado à medida que se fortalece a unidade de ação dos trabalhadores nos sindicatos, federações e confederações, isto é, nos quadros da organização sindical existente no país. O movimento sindical tem avançado igualmente à medida em que os trabalhadores aprendem a utilizar as conquistas da legislação social vigente e procuram concretizá-la e aperfeiçoá-la, influindo no Parlamento, com a pressão de massas, para a aprovação de novas leis. Os sindicatos e as demais organizações profissionais não devem servir a objetivos partidários, mas precisam ser instrumentos da unidade dos trabalhadores de todas as tendências ideológicas e políticas, na luta por suas reivindicações imediatas, pelo direito de greve, pelo melhoramento da previdência social, etc. Simultaneamente, cabe aos sindicatos um grande papel no amplo movimento nacionalista e democrático.

Os camponeses constituem a massa mais numerosa da nação e representam uma força cuja mobilização é indispensável ao desenvolvimento consequente das lutas do povo brasileiro. $\mathrm{O}$ movimento camponês se encontra, entretanto, bastante atrasado, sendo baixíssimo o seu nível de organização. Para impulsionar o movimento camponês, é preciso partir do seu nível atual, tomando por base as reivindicações mais imediatas e viáveis, como o salário mínimo, a baixa do arrendamento, a garantia contra os despejos e evitando, no trabalho prático, as palavras de ordem radicais que ainda não encontram condições maduras para a sua realização. Também no campo, a experiência demonstra que a atuação através de formas legais de luta e de organização é aquela que permite alcançar êxitos para as massas. Assim é que tem progredido, além das associações rurais e cooperativas, a organização dos assalariados e semiassalariados em sindicatos, que já obtiveram vitórias em contendas com fazendeiros. Tem grande importância a defesa jurídica dos direitos já assegurados aos camponeses. A ação de massas se mostra indispensável para vencer a resistência dos latifundiários no Parlamento e conquistar a aprovação de leis que correspondam aos interesses dos trabalhadores agrícolas, inclusive a elaboração de uma legislação trabalhista adequada ao campo.

As camadas médias urbanas são extremamente sensíveis às reivindicações de caráter nacionalista e democrático. Aos pequenos negociantes, ao funcionalismo civil e militar e a outros setores da pequena burguesia cabe um posto destacado nas lutas do povo brasileiro. Importante papel desempenha a intelectualidade, que em sua esmagadora maioria está interessada no progresso e na emancipação nacional. Como setor mais 
combativo da intelectualidade, o movimento estudantil tem dado importante contribuição às lutas do povo brasileiro.

A unidade dos estudantes das mais diversas tendências doutrinárias e políticas é um fator essencial para o fortalecimento das organizações estudantis, universitárias e secundárias, que têm sido baluartes da frente única nacionalista e democrática. Seguindo o exemplo dos estudantes, a juventude dos sindicatos, dos clubes esportivos e recreativos pode unir-se e obter vitórias na luta por suas reivindicações.

A formulação dos objetivos comuns, num processo de discussão democrática, vai-se tomando necessária para a frente única à medida que aumenta a envergadura de suas tarefas. Os comunistas são de opinião que uma plataforma de frente única deve incluir os seguintes pontos fundamentais:

$\left(1^{\circ}\right)$ Política exterior independente e de paz. Estabelecimento de relações amistosas com todos os países, acima de diferenças de regime social, na base de respeito mútuo da integridade territorial e da soberania, da não agressão, da não intervenção nos assuntos internos e da igualdade de direitos e vantagens recíprocas. Desvinculação de compromissos com quaisquer blocos militares, denúncia de tratados belicistas e de ajustes antinacionais como o da cessão de Fernando de Noronha. Apoio às propostas que visem ao alívio da tensão internacional e ao término da "guerra fria". Apoio às lutas de libertação nacional de todos os povos.

$\left(2^{\circ}\right)$ Desenvolvimento independente e progressista da economia nacional. Intercâmbio comercial com todos os países, inclusive socialistas. Desenvolvimento da iniciativa estatal nacionalista nos setores do petróleo, energia elétrica, siderurgia, minerais estratégicos e outros setores básicos. Proteção e estímulo da iniciativa privada nacional. Execução de um programa federal para o desenvolvimento das regiões mais atrasadas do país e, em particular, incentivo à industrialização do nordeste. Revogação dos privilégios cambiais ou de qualquer outra ordem concedidos ao capital estrangeiro, selecionando suas inversões de acordo com os interesses do desenvolvimento do país e sem prejuízo dos empreendimentos nacionais. Dar preferência aos financiamentos em geral, governamentais ou não, sempre que não condicionados a exigências políticas e escolhendo livremente aqueles que, seja qual for sua procedência, ofereçam melhores condições no que se refere a juros, prazos de amortização e assistência técnica. $\left(3^{\circ}\right)$ Medidas de reforma agrária em favor das massas camponesas. Redução das taxas de arrendamento e prolongamento dos seus prazos contratuais. Defesa dos camponeses contra a grilagem e os despejos. Facilitar aos camponeses o acesso à terra, particularmente junto aos centros urbanos e vias de comunicação. Garantia da posse da terra e entrega de títulos de propriedade aos atuais posseiros. Aplicação dos direitos dos trabalhadores do campo já consolidados em lei. Legislação trabalhista adequada ao campo. Facilitar aos camponeses o crédito bancário, particularmente do Banco do Brasil, os transportes, a armazenagem e a assistência técnica.

$\left(4^{\circ}\right)$ Elevação do nível de vida do povo. Combate enérgico à inflação e à carestia. Equilíbrio orçamentário e política tributária que não sacrifique as massas nem prejudique as atividades produtivas. Salários e vencimentos que assegurem melhores condições de vida aos trabalhadores e ao funcionalismo. Democratização dos órgãos governamentais de controle do abastecimento e dos preços, de tal maneira que possam servir efetivamente aos interesses das massas populares. Aumento das verbas destinadas à educação e saúde do povo. Estímulo ao desenvolvimento da cultura nacional. Aplicação efetiva e melhoria da legislação trabalhista.

$\left(5^{\circ}\right)$ Consolidação e ampliação da legalidade democrática. Garantia dos direitos democráticos contidos na Constituição. Abolição completa das discriminações políticas e ideológicas. Garantia do direito de greve e dos direitos sindicais dos trabalhadores. Direito de voto aos analfabetos, bem como aos soldados e marinheiros.

Os comunistas apresentam esta plataforma para um amplo debate do qual possa resultar a formulação unitária dos objetivos comuns das forças nacionalistas e democráticas.

A frente única nacionalista e democrática acumula forças à medida que luta por soluções positivas para os problemas colocados na ordem do dia, realizando-as na proporção de sua capacidade e das condições favoráveis de cada momento. A exigência dessas soluções positivas para os problemas brasileiros conduz, inevitavelmente, à necessidade de um governo que possa aplicar com firmeza em todas as esferas da política interna e exterior a política de desenvolvimento e de emancipação reclamada pelo povo brasileiro. A luta das correntes nacionalistas e democráticas para alcançar modificações na composição e na política do 
governo atual assume, e tende a assumir cada vez mais, o caráter de luta por um governo de coligação nacionalista e democrática.

Um governo nacionalista e democrático pode ser conquistado pela frente única nos quadros do regime vigente e aplicar uma política externa de independência e de paz, assegurar o desenvolvimento independente e progressista da economia nacional, tomar medidas em favor do bem-estar das massas, garantir as liberdades democráticas.

O desenvolvimento da situação no país indica que esta orientação política pode vir a ser gradualmente realizada por um ou por sucessivos governos que se apoiem na frente única nacionalista e democrática.

Um governo nacionalista e democrático dependerá fundamentalmente, do apoio das massas e, por isto, o ascenso do movimento de massas não poderá deixar de influir no sentido da radicalização de sua composição e de sua política. Esta radicalização será também resultado da necessidade inevitável de medidas mais enérgicas e profundas diante dos atentados do imperialismo norte-americano e das forças entreguistas e reacionárias no país.

O curso dos acontecimentos no Brasil indica, por conseguinte, a possibilidade real de um processo em que, sob a pressão das ações independentes das massas e diante da necessidade de medidas mais consequentes contra o inimigo, principal da nação, um governo de coligação nacionalista e democrática abrirá caminho para uma nova correlação de forças, que possibilite completar as transformações revolucionárias exigidas pelo desenvolvimento econômico e social de nossa Pátria.

Ainda que dispostos a participar dos governos de caráter nacionalista e democrático, os comunistas os apoiarão de modo resoluto, mesmo que não venham a fazer parte de sua composição.

\section{VI - O caminho pacífico da revolução brasileira}

Os comunistas consideram que existe hoje em nosso país a possibilidade real de conduzir, por formas e meios pacíficos, a revolução anti-imperialista e antifeudal. Nestas condições, este caminho é o que convém à classe operária e a toda a nação. Como representantes da classe operária e patriotas, os comunistas, tanto quanto deles dependa, tudo farão para transformar aquela possibilidade em realidade.

O caminho pacífico da revolução brasileira é possível em virtude de fatores como a democratização crescente da vida política, o ascenso do movimento operário e o desenvolvimento da frente única nacionalista e democrática em nosso país. Sua possibilidade se tornou real em virtude das mudanças qualitativas da situação internacional, que resultaram numa correlação de forcas decididamente favorável à classe operária e ao movimento de libertação dos povos.

O caminho pacífico significa a atuação de todas as correntes antiimperialistas dentro da legalidade democrática e constitucional, com a utilização de formas legais de luta e de organização de massas. É necessário, pois, defender esta legalidade e estendê-la, em benefício das massas. $\mathrm{O}$ aperfeiçoamento da legalidade, através de reformas democráticas da Constituição, deve e pode ser alcançado pacificamente, combinando a ação parlamentar e a extraparlamentar.

O povo brasileiro pode resolver pacificamente os seus problemas básicos com a acumulação, gradual mas incessante, de reformas profundas e consequentes na estrutura econômica e nas instituições políticas, chegando-se até à realização completa das transformações radicais colocadas na ordem do dia pelo próprio desenvolvimento econômico e social da nação.

A fïm de encaminhar a solução de seus problemas vitais, o povo brasileiro necessita conquistar um governo nacionalista e democrático. Esta conquista poderá ser efetuada através dos seguintes meios mais prováveis:

1. Pela pressão pacífica das massas populares e de todas as correntes nacionalistas, dentro e fora do Parlamento, no sentido de fortalecer e ampliar o setor nacionalista do atual governo, com o afastamento do poder de todos os entreguistas e sua substituição por elementos nacionalistas.

2. Através da vitória da frente única nacionalista e democrática nos pleitos eleitorais.

3. Pela resistência das massas populares, unidas aos setores nacionalistas do Parlamento, das forças armadas e do governo, para impor ou restabelecer a legalidade democrática, no caso de tentativas de golpe por 
parte dos entreguistas e reacionários, que se proponham implantar no país uma ditadura a serviço dos monopólios norte-americanos.

O complexo desenvolvimento da vida política nacional é que determinará como será realizada a conquista de um governo nacionalista e democrático.

Sejam quais forem as vicissitudes que o povo brasileiro tiver de enfrentar para resolver pacificamente os seus problemas, será sempre necessário o amplo desenvolvimento da luta de classes do proletariado, dos camponeses e das camadas médias urbanas em defesa dos seus interesses específicos e dos interesses gerais da nação.

A escolha das formas e meios para transformar a sociedade brasileira não depende somente do proletariado e das demais forças patrióticas. No caso em que os inimigos do povo brasileiro venham a empregar a violência contra as forças progressistas da nação, é indispensável ter em vista outra possibilidade a de uma solução não pacífica. Os sofrimentos que recaírem sobre as massas, em tal caso, serão da inteira responsabilidade dos inimigos do povo brasileiro.

Quanto aos comunistas, tudo farão para alcançar os objetivos vitais do proletariado e do povo por um caminho que, sendo de luta árdua, de contradições e de choques, pode evitar o derramamento de sangue na insurreição armada ou na guerra civil. Os comunistas confiam em que, nas circunstâncias favoráveis da situação internacional, as forças antiimperialistas e democráticas terão condições para garantir o curso pacífico da revolução brasileira.

\section{VII - Pela vitória da frente única nacionalista e democrática nas eleições}

A experiência política do país vem demonstrando que o povo já alcançou importantes vitórias dentro do Parlamento e dos órgãos legislativos nos Estados e municípios. Esta experiência também já demonstrou que é possível eleger nacionalistas e democratas para os postos executivos. As eleições constituem, portanto, um acontecimento de excepcional importância em nossa vida política.
As eleições, no Brasil, ainda estão submetidas a sérias restrições antidemocráticas. Certas destas restrições derivam do poder econômico e político concentrado em massas das classes exploradoras e são inevitáveis mesmo nas melhores condições da democracia burguesa. Outras, porém, são restrições possíveis de eliminar ainda no regime atual, à medida que avança o processo de democratização. Os comunistas lutam, por isto, pela extensão do direito de voto aos analfabetos, bem como aos soldados e marinheiros. Lutam, igualmente, pela restituição da legalidade ao Partido Comunista, fazendo cessar uma discriminação anticonstitucional consumada numa conjuntura reacionária e mantida até hoje em flagrante desrespeito aos postulados da Carta Magna.

As restrições antidemocráticas que ainda pesam sobre o processo eleitoral não impedem, porém, a afirmação da sua crescente importância para determinar os rumos da vida política do país. Combinadas a outras formas pacíficas e legais de lutas de massas, as eleições podem dar vitórias decisivas ao povo. Massas de milhões vêm utilizando o voto para expressar a sua vontade e influir nos destinos da nação. A participação mais entusiástica nas eleições é, assim, um dever para os comunistas.

Esta participação não visa exclusivamente a obter pequenos proveitos imediatos e a utilizar uma oportunidade para fazer agitação de palavras de ordem. O objetivo fundamental da participação dos comunistas nas eleições consiste em eleger para os postos executivos e legislativos os candidatos da frente única, que possam fortalecer os setores nacionalistas do Parlamento e do governo. Todo o trabalho eleitoral dos comunistas, seja em âmbito nacional como em estadual e municipal, deve ser considerado uma parte do trabalho geral de formação e desenvolvimento da frente única, visando sempre à mudança da correlação de forças políticas e à conquista de um governo nacionalista e democrático.

Os comunistas se empenham, por este motivo, em contribuir para a constituição de amplas coligações eleitorais, que tenham força para levar à vitória os candidatos da frente única. A ação independente dos comunistas se realizará, não fora, mas dentro da frente única. Lutando, na medida de suas possibilidades, para eleger seus próprios candidatos, os comunistas não adotam, porém, uma posição exclusivista, colocam acima de tudo a necessidade de desenvolver e fortalecer a frente única e consideram que a vitória de candidatos não comunistas da frente única é também sua vitória. 
Esta orientação contribuirá para aprofundar nacionalmente e em cada local a polarizado em processo entre nacionalistas e entreguistas, a fim de isolar e derrotar os candidatos comprometidos com o imperialismo norte-americano.

Buscando formar amplas coligações eleitorais, que levem à vitória os nacionalistas e os democratas, é necessário ter em vista a composição de classe mais ou menos heterogênea dos partidos políticos brasileiros, sem, entretanto, estabelecer identidade entre eles. Os comunistas apoiam os elementos nacionalistas e democratas que existem em todos os Partidos. Tais elementos constituem uma ala considerável do PSD, a qual tem lutado com relativo êxito contra a ala reacionária do mesmo partido, ligada aos latifundiários mais retrógrados e a interesses imperialistas. Em proporção menor, existem elementos nacionalistas na UDN que se chocam com a alta direção nacional do seu partido, ainda dominada por conhecidos golpistas e porta-vozes do imperialismo norte-americano. Partidos como o PTB, o PSP e o PSB, que possuem maior base popular nos centros urbanos, apresentam uma tendência nacionalista e democrática mais acentuada. O PTB, cujo maior contingente eleitoral provém das massas trabalhadoras, de modo geral orienta-se por uma política nacionalista e popular. $\mathrm{O}$ mesmo ocorre com o PSB, cuja base social repousa em setores da pequena burguesia urbana e, em particular, da intelectualidade. Tanto o PTB como o PSB já defendem plataformas nacionalistas e democráticas.

À medida que se desenvolve o capitalismo no país, os partidos políticos brasileiros adquirem um caráter cada vez mais estável e nacional. Em virtude, porém, da extrema desigualdade de desenvolvimento que se verifica entre as diferentes regiões, os partidos políticos não puderam ainda superar as divergências, por vezes agudas, que lavram entre as suas seções estaduais e até mesmo municipais. Esta circunstância não pode deixar de ser levada em conta, a fim de distinguir, com justeza, as variações de orientação entre os diretórios nacionais, estaduais e municipais.

Os comunistas apoiam nas eleições os partidos, alas e seções de partidos e personalidades de atuação nacionalista reconhecida, não confundindo-os, porém, com os falsos nacionalistas, que procuram enganar o povo com a sua demagogia eleitoreira.

É com esta visão das eleições e de suas perspectivas essenciais que os comunistas se mobilizam para tomar parte nos pleitos de 1958 e 1960.

\section{VIII - Fortalecer o Partido para a aplicação de uma nova política}

O proletariado brasileiro necessita de uma vanguarda marxistaleninista organizada e combativa a fria de realizar sua política de classe.

O Partido Comunista Brasileiro, que é esta vanguarda, deve ser capaz de cumprir o seu papel na ação política concreta.

Isto exige que o nosso Partido se depure de persistentes defeitos e adquira qualidades novas. O subjetivismo, que exerceu longo domínio em nossas fronteiras, deve ser combatido em profundidade, através da reeducação dos dirigentes e militantes no espírito de uma nova política, que emane diretamente das condições objetivas de nosso país e seja a correta aplicação dos princípios universais do marxismo-leninismo às originais particularidades concretas do desenvolvimento histórico nacional. O abandono dos princípios universais do marxismo-leninismo, como síntese científica da experiência do movimento operário mundial, conduz inevitavelmente à desfiguração do caráter de classe do Partido, e à degenerescência revisionista. Mas o desconhecimento das particularidades concretas do próprio país condena o Partido, irremediavelmente, à impotência sectária e dogmática.

As concepções dogmáticas e sectárias, que nas condições atuais de nosso Partido constituem o perigo fundamental a combater, se opõem de modo radical ao próprio caráter da missão que os comunistas têm a cumprir. A frente da classe operária deve estar um Partido que saiba dirigir a luta pelos objetivos revolucionários na ação política corrente, diária, determinada pelas próprias exigências do movimento real das massas, das classes e das forças políticas. A esta característica essencial se subordinam as atividades de agitação e propaganda, do trabalho de massas e de organização do Partido.

Para que os comunistas possam cumprir sua importante tarefa, devem estar a serviço das massas e lançar-se decididamente à atividade junto às massas. Ao invés de se voltarem apenas para o trabalho interno do Partido, precisam dedicar o fundamental de suas energias à atuação legal nas organizações de massas e aí exercer uma função eminentemente construtiva. É indispensável, por conseguinte, tomar as medidas adequadas para que o maior número possível de quadros, militantes e dirigentes, realizem atividades legais entre as massas. Participando das lutas de massas 
nos movimentos reivindicativos, nas campanhas políticas, nas eleições, os comunistas não tem outro fim senão o de tornar vitoriosas as aspirações das massas, aprender com elas e educá-las a partir do nível de consciência que já atingiram. Os comunistas devem ser em toda parte trabalhadores isentos de exclusivismo, abnegados e consequentes, pela construção da frente única nacionalista e democrática.

O Comitê Central concita a todos os militantes a empenharem-se no fortalecimento do Partido para torná-lo o instrumento adequado à execução vitoriosa da nova política traçada nesta Declaração, que deve guiar, de agora em diante, toda a atividade do Partido.

O Comitê Central do PCB

Março de 1958 